
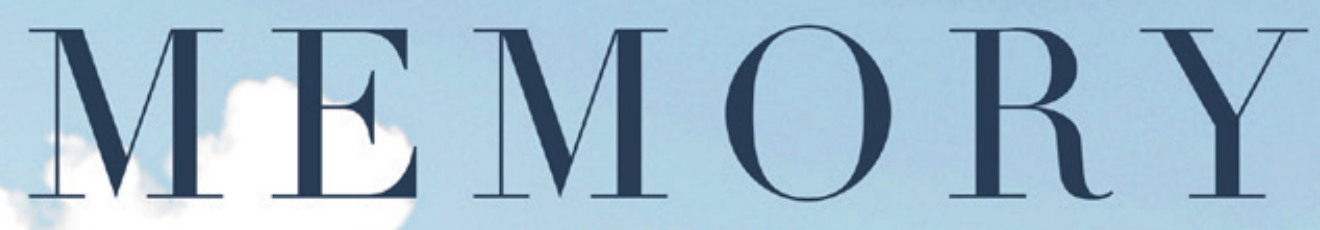

and the future of
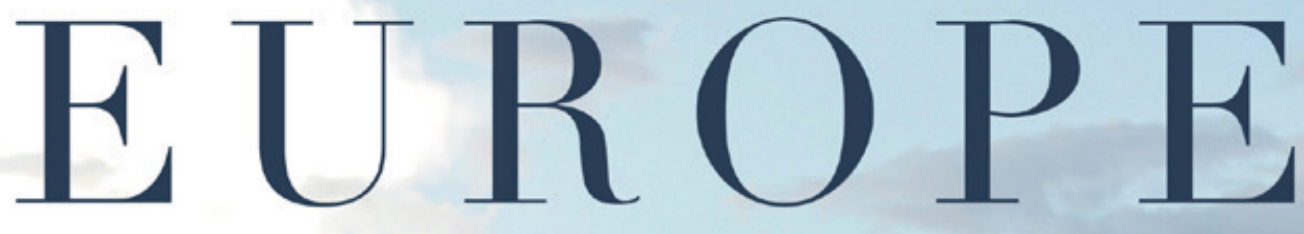

Rupture and integration in the wake of total war

PETER J. VEROVŠEK 


\section{Memory and the future of Europe}

\section{MANCHESTER 1824}

Manchester University Press 
Peter J. Verovšek - 9781526143112 Downloaded from manchesterhive.com at $04 / 26 / 2023$ 01:40:30PM via free access 


\section{Memory and the future of Europe}

Rupture and integration in the wake of total war

Peter J. Verovšek

Manchester University Press 
Copyright (C) Peter J. Verovšsek 2020

The right of Peter J. Verovšek to be identified as the author of this work has been asserted by him in accordance with the Copyright, Designs and Patents Act 1988.

Published by Manchester University Press Altrincham Street, Manchester M1 7JA www.manchesteruniversitypress.co.uk

British Library Cataloguing-in-Publication Data

A catalogue record for this book is available from the British Library

ISBN 9781526143105 hardback

First published 2020

The publisher has no responsibility for the persistence or accuracy of URLs for any external or third-party internet websites referred to in this book, and does not guarantee that any content on such websites is, or will remain, accurate or appropriate.

COVER IMAGE: Memorial to the Murdered Jews of Europe, Berlin, Germany. (C) Rob Pinney

Typeset by Newgen Publishing UK 